\title{
Pengaruh Diversity, Turnover Intention dan Kepuasan Kerja Terhadap Pengembangan Potensi Aparatur Desa Bintan Buyu Kabupaten Bintan
}

\author{
Nurhasanah, Risdy Absari Indah Pratiwi
}

Dosen Program Studi Manajemen Universitas Maritim Raja Ali Haji, Tanjungpinang, Indonesia

\begin{abstract}
ABSTRAK : Penelitian ini bertujuan untuk menjelaskan pengaruh Diversity, Turnover Intention dan Kepuasan Kerja Terhadap Pengembangan Potensi Aparatur Desa Bintan Buyu Kabupaten Bintan. Populasi penelitian adalah aparatur Desa di Kabupaten Bintan, Provinsi Kepulauan Riau. Jumlah sampel sebanyak 73 Aparatur Desa di Kecamatan Bintan Buyu Kabupaten Bintan yang terdiri dari 6 Desa yaitu Desa Tembeling Tanjung, Desa Tembeling, Desa Bintan Buyu, Desa Penaga, Desa Pengujan dan Desa Pangkil. Untuk efisiensi dan efektifitas penelitian maka Aparatur Desa di Desa Pangkil tidak masuk ke dalam data karena akses ke Desa Pangkil melalui jalur laut. Jenis penelitian ini adalah penelitian kuantitatif. Pada kuesioner dilakukan test validitas dan reliabilitas. Data diuji melalui Uji Asumsi Klasik yaitu Uji Normalitas Data, Uji Multikolinearitas Data dan Uji Heteroskedastisitas Data. Data dianalisis menggunakan analisis regresi linear berganda, termasuk uji t, uji $\mathrm{F}$ dan koefisien determinasi. Hasil penelitian menunjukkan bahwa secara parsial variable Diversity (X1) dan variable Kepuasan Kerja (X3) berpengaruh signifikan terhadap Pengembangan Potensi, sedangkan variable Turnover Intention (X2) secara parsial tidak berpengaruh signifikan terhadap variable Pengembangan Potensi (Y). Hasil uji F diperoleh nilai $\mathrm{F}$ hitung 53.548 dengan nilai $\mathrm{F}$ tabel 2.74 mengidentifikasikan bahwa variabel Diversity, Turnover Intention dan Kepuasan Kerja secara simultan berpengaruh terhadap variabel Pengembangan Potensi (Y). Berdasarkan uji koefisien determinasi, sekitar $70 \%$ variabel Pengembangan Potensi dipengaruhi oleh variable Diversity, Turnover Intention dan Kepuasan Kerja. Dan 30\% dipengaruhi oleh faktor lainnya yang tidak dijelaskan didalam penelitian ini.
\end{abstract}

Kata Kunci: Diversity, Kepuasan Kerja, Pengembangan Potensi,Turnover Intention.

ABSTRACT : This study aims to explain the effect of Diversity, Turnover Intention and Job Satisfaction on the Development of Potential Apparatus of Bintan Buyu Village, Bintan Regency. The study population was the Village apparatus in Bintan Regency, Riau Islands Province. The number of samples were 73 Village Apparatuses in Bintan Buyu Subdistrict, Bintan Regency consisting of 6 Villages, namely Tembeling Tanjung Village, Tembeling Village, Bintan Buyu Village, Penaga Village, Pengujan Village and Pangkil Village. For the efficiency and effectiveness of the research, the Village Apparatus in Pangkil Village is not included in the data because of access to Pangkil Village by sea. This type of research is quantitative research. The validity and reliability tests were performed on the questionnaire. Data were tested through the Classical Assumption Test, namely the Data Normality Test, the Data Multicollinearity Test and the Data Heteroscedasticity Test. Data were analyzed using multiple linear regression analysis, including $t$ test, $F$ test and the coefficient of determination. The results showed that the Diversity (X1) and Job Satisfaction (X3) variables partially had a significant effect on Potential Development, while the Turnover Intention variable (X2) partially had no significant effect on the Potential Development variable (Y). F test results obtained calculated $F$ value of 53,548 with $F$ value of table 2.74 to identify that the 
variable Diversity, Turnover Intention and Job Satisfaction simultaneously influence the Potential Development variable (Y). Based on the coefficient of determination test, about $70 \%$ of the Potential Development variable is influenced by the Diversity, Turnover Intention and Job Satisfaction variables. And $30 \%$ is influenced by other factors not explained in this study.

Keywords: Diversity, Job Satisfaction, Potential Development, Turnover Intention.

Email Address : nurhasanah@umrah.ac.id

\section{Pendahuluan}

Berdasarkan Undang-Undang Nomor 6 Tahun 2014 tentang Desa, perhatian yang besar ditujukan kepada pedesaan, hal itu didasarkan pada kenyataan bahwa desa merupakan tempat berdiamnya sebagian besar rakyat Indonesia, kedudukan desa dan masyarakat desa merupakan dasar landasan kehidupan bangsa dan negara Indonesia. Desa adalah kesatuan masyarakat hukum yang memiliki batas wilayah yang berwenang untuk mengatur dan mengurus urusan pemerintahan, kepentingan masyarakat setempat berdasarkan prakarsa masyarakat, hak asal usul, dan/atau hak tradisional yang diakui dan dihormati dalam sistem pemerintahan Negara Kesatuan Republik Indonesia. (UU No. 6 Tahun 2014).

Undang-Undang tentang Pemerintahan Daerah mengakui adanya otonomi yang dimiliki oleh Desa dan kepada kepala desa dapat diberikan penugasan ataupun pendelegasian dari pemerintah atau pemerintah daerah untuk melaksanakan urusan pemerintahan tertentu. Keberhasilan atau kegagalan penyelenggaraan pemerintahan desa sangat ditentukan oleh kompetensi aparatur desa, baik kompetesi pengetahuan, kompetensi keterampilan, maupun kompetensi sikap.

Sejauh ini, peningkatan aparatur desa didalam pengoptimalan kinerja belum cukup memuaskan, terkait Diversinity (keragaman), Turnover Intention (keinginan berpindah), dan Satisfaction (kepuasan) didalam meningkatkan nilai prestasi kerja. Keprihatinan lainnya adalah terjadinya strereotip, akibatnya adalah di tempat kerja akan tercipta konflik antara kelompok orang-orang dan mengakibatkan semakin sedikitnya interaksi dan kerjasama ditempat kerja. Maka dari itu sangat penting untuk mengelola keragaman (Manthis). Hal tersebut akan menjadi salah satu factor pendorong untuk mencoba pekerjaan lainnya atau keinginan untuk berpindah pekerjaan serta menimbulkan rasa

ketidakpuasannya dalam berkerja. Penelitian ini berfokus pada pengembangan potensi aparatur

Desa yang memiliki peranan vital dalam terwujudnya visi dan misi pemerintah.

Peneliti melakukan penelitian Desa di Kabupaten Bintan Provinsi Kepulauan Riau dan berfokus pada Desa di Kecamatan Teluk Bintan Kabupaten Bintan Provinsi Kepulauan Riau yang berjumlah enam Desa yaitu Desa Tembeling, Desa Bintan Buyu, Desa Penaga, Desa Pengujan, Desa Pangkil dan Desa Tembeling Tanjung yang sekarang telah melakukan pemekaran Desa menjadi Kelurahan. Permasalahan yang sering terjadi dilapangan adalah teknis kinerja yang kurang terhadap implementasi didalam interaksi setiap pegawai. Sumberdaya manusia yang beragam, factor penyebab keinginan pindah kerja hingga kepuasan kerja menjadi indikasi terhadap pengembangan potensi SDM tersebut. Hal ini cenderung menimbulkan statisme kinerja yang tidak stabil, dikarenakan tingkat kinerja yang minim cenderung ragu dalam setiap pengaplikasian atau penerapan bidang kerja, hal ini masih ditemui di beberapa desa yang terdapat di Kabupaten Bintan, Kecamatan Teluk Bintan. Peneliti menjustifikasi bahwa pada keragaman 
sumberdaya di Desa yang berada di Kecamatan Bintan Buyu dilihat dari perbedaan lama berkerja dan status pegawai tetap dan tidak tetap. Kejenuhan akan pekerjaan yang monoton menstimulus rasa ingin berpindah pekerjaan. Masih banyak aparatur kurang memiliki skill pemahaman yang memadai untuk penyelenggaraan pemerintahan desa, sehingga belum maksimal dalam mewujudkan sesuai visi misi Kabupaten Bintan. Indikasi masalah tersebut menarik untuk dikaji melalui suatu penelitian ilmiah, sehingga dipilih judul penelitian "Pengaruh Diversity, Turnover Intention dan Kepuasan Kerja terhadap Pengembangan Potensi Aparatur Desa Bintan Buyu, Kecamatan Teluk Bintan, Kabupaten Bintan, Kepulauan Riau".

Tujuan dari penelitian ini adalah:

1. Untuk mengetahui pengaruh Diversity (Keragaman) Aparatur desa terhadap Pengembangan Potensi Aparatur Desa.

2. Untuk mengetahui pengaruh Turnover Intention terhadap Pengembangan Potensi Aparatur Desa.

3. Untuk mengetahui pengaruh Kepuasan Kerja terhadap Pengembangan Potensi Aparatur Desa.

4. Untuk mengetahui Diversity, Turnover Intention dan Kepuasan Kerja terhadap pengembangan Potensi Aparatur Desa.

\section{Metodologi Penelitian}

\section{Rancangan Penelitian}

Penelitian ini dirancang berdasarkan hipotesis yang diilustrasikan dalam kerangka pemikiran sebagai berikut:

\section{Gambar 1. Kerangka Pemikiran}

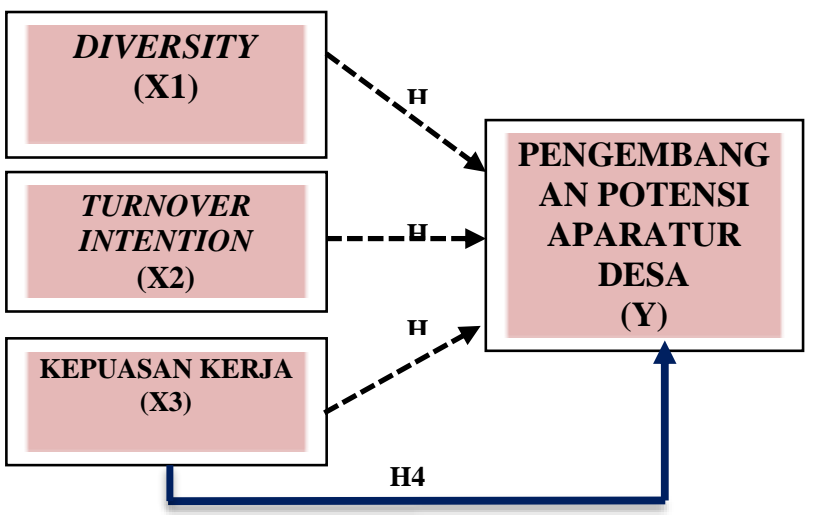

Sumber: Olahdata Penulis

\section{H1: Diduga Diversity berpengaruh terhadap} pengembangan Potensi Desa

Diversity merupakan keragaman yang ada perbedaan di antara orang-orang karena usia, jenis kelamin, ras, etnis, agama, orientasi seksual, latar belakang sosial ekonomi, pendidikan, pengalaman, penampilan fisik, kemampuan/ketidakmampuan, dan karakteristik lain yang digunakan untuk membedakan antara orang yang satu dengan yang lainnya, keberagaman tersebut menciptakan potensi yang berbeda setiap individunya dan potensi tersebut dapat dikembangkan sesuai arah visi dan misi.

\section{H2: Diduga Turnover Intention berpengaruh terhadap Pengembangan Potensi Desa}

Turnover Intention merupakan tantangan khusus bagi pengembangan sumber daya manusia. Karena kejadian-kejadian tersebut tidak dapat diperkirakan, kegiatan-kegiatan pengembangan harus mempersiapkan setiap saat pengganti pegawai yang keluar. Rasa ingin berpindah yang tinggi dapat mempengaruhi pengembangan potensi yang dimiliki, karena rasa ingin berpindah tersebut tercipta karena pola monoton terhadap pekerjaan, dengan rasa ingin berpindah tersebut menjadi Aparatur lebih berusaha bersifat kreatif dan inovatif dalam menjalankan pekerjaannya.

H3: Diduga Kepuasan Kerja berpengaruh terhadap Pengembangan Potensi Desa

Aparatur desa yang terdiri dari kepala desa, sekretaris desa, bendahara dan BPD hendaknya memiliki Kualitas dalam hal dan pengelolaan Desa. Jika aparatur desa memiliki kualitas maka akan lebih mudah dalam mengatur dan mengelola pekerjaan yang diberikan sesuai dengan job Diskripsionnya. Kepuasan kerja adalah tanggapan afektif atau emosi terhadap berbagai fase pekerjaan seseorang. Pengertian ini menyatakan bahwa kepuasan kerja bukanlah konsep tunggal. Tepatnya, orang bisa relatif puas dengan satu aspek atau beberapa aspek lain dari 
pekerjaannya. Tingkat kepuasan dalam berkerja tersebut akan menggiring potensi berkembang kearah yang baik atau sebaliknya.

\section{H4: Diduga Diversity, Turnover Intention dan Kepuasan Kerja berpengaruh terhadap Pengembangan Potensi Desa}

Keberagaman sumberdaya manusia, tingkat keinginan untuk berpindah kerja yang tinggi dan kepuasan kerja akan mempengaruhi dalam pengembangan potensi. Hal ini disebabkan pengembangan potensi didasari pada individu itu sendiri di dalam kelompok.

\section{Jenis dan Sumber Data}

Penelitian ini menggunakan metode kuantatif, penelitian kuantitatif merupakan prosedur meneliti yang menghasilkan data berupa angkaangka hasil penelolaan dari sumber data primer. Penelitian ini menggunakan data primer dan data sekunder. Data primer didapat dari kuesioner yang berdasarkan indicator variable penelitian dengan jumlah 73 responden. Data sekunder didapat dari referensi penelitian terdahulu, buku dan referensi lainnya.

\section{Populasi dan sampel}

Populasi penelitian ini adalah aparatur Desa di Kabupaten Bintan, Provinsi Kepulauan Riau. Jumlah sampel sebanyak 73 Aparatur Desa di Kecamatan Bintan Buyu Kabupaten Bintan yang terdiri dari 6 Desa yaitu Desa Tembeling Tanjung, Desa Tembeling, Desa Bintan Buyu, Desa Penaga, Desa Pengujan dan Desa Pangkil. Untuk efisiensi dan efektifitas penelitian maka Aparatur Desa di Desa Pangkil tidak masuk ke dalam data karena akses ke Desa Pangkil melalui jalur laut.

\section{Metode Pengelolaan Data}

Pengelolaan data menggunakan aplikasi SPSS versi 24, dalam pengelolaan data tersebut dilakukan uji kualitas data (uji validitas dan reliabilitas), uji asumsi klasik (normalitas, multikolinearitas, heteroskedastisitas) dan menganalisis regresi linear berganda melalui uji $\mathrm{t}$, uji $\mathrm{F}$ dan determinasi $\mathrm{R}^{2}$.

\section{Metode Analisis}

Metode analisis data dalam penelitian ini dengan menggunakan alisis regresi linear berganda,model analisis regresi linear berganda dalam penelitian ini adalah sebagai berikut :

$\mathrm{Y}=a+\mathrm{b} 1 \times 1+\mathrm{b} 2 \times 2+\mathrm{b} 3 \times 3+e$

$$
\begin{aligned}
& \text { Dimana : Y : Pengembangan Potensi Desa } \\
& \text { : Konstansta } \\
& \text { b1,b2 : Koefisien Regresi } \\
& \mathrm{x} 1 \quad \text { : Diversity } \\
& \text { x2 : TurnOver Intention } \\
& \text { x3 : Kepuasan Kerja } \\
& e \quad \text { : error term }
\end{aligned}
$$

\section{Hasil dan Pembahasan}

\section{Kajian Teori Penelitian}

Pada Penelitian ini mengkaji teori mengenai Diversity, Turnover Intention, Kepuasan Kerja Dan Pengembangan Potensi Aparatur Desa. Aparatur dan pamong desa merupakan sarana pendukung kelancaran dan ketertiban pemerintahan desa. Perannannya sangat penting bagi perubahan dan tingkat perkembangan desa. Dalam susunan Aparatur Desa terdapat keberagaman sumberdaya manusia atau Diversity SDM. Menurut Cox dalam Wijaya (2014) Diversity (keragaman) adalah variasi dari identitas sosial dan budaya antara orang-orang yang ada bersama-sama dalam sebuah pekerjaan atau pengaturan pasar. Keragaman merupakan banyak perbedaan individu dan persamaan yang ada di antara orang. Ada banyak dimensi yang berbeda atau komponen keragaman yang membuat kita semua unik dan berbeda dari orang lain. Manajemen keragaman sebagai pendekatan secara eksplisit yang berkaitan dengan integrasi isu-isu manajemen dengan masalah bisnis dan pengembangan budaya tempat kerja yang mengakui kebutuhan untuk mengelola persamaan dan perbedaan antara kontributor organisasi. Menurut Gardenswartz dan Rowe dalam Wijaya (2014), model pengukuran keragaman meliputi 4 lapisan, yaitu:

1. Personality (extraversion, agreeableness, conscientiousness, neuoriticism, openness to experiences).

2. Dimensi Internal (usia, etnis, jenis kelamin, orientasi seksual, cacat tubuh).

3. Dimensi Eksternal (status perkawinan, lokasi geografis, penghasilan, kebiasaan 
pribadi, kebiasaan rekreasi, agama, latar belakang pendidikan, pengalaman kerja, penampilan, status orang tua, kedudukan perkawinan).

4. Dimensi Organisasi (tingkat fungsional, konten kerja, minat, departemen, durasi kerja, jenis pekerjaan, lokasi kerja).

Didalam kelompok kerja yang terikat biasanya membuat pekerjaan yang diterima menjadi lebih monoton sehingga menimbulkan kejenuhan dalam berkerja, hal ini menyebabkan rasa ingin berpindah pekerjaan lainnya. (Menurut Harnoto (2002), Turnover Intentions adalah kadar atau intensitas dari keinginan untuk keluar dari perusahaan, banyak alasan yang menyebabkan timbulnya turnover intentions ini dan diantaranya adalah keinginan untuk mendapatkan pekerjaan yang lebih baik." Ini menjelaskan bahwa Turnover Intentions pada dasarnya adalah keinginan untuk meninggalkan (keluar) dari perusahaan. Hartono (dalam Wulandari 2017) menyatakan Turnover Intentions ditandai oleh berbagai hal yang menyangkut perilaku karyawan, antara lain:

1. Absensi yang meningkat, karyawan yang berkeinginan untuk melakukan pindah kerja, biasanya ditandai dengan absensi yang semakin meningkat.

2. Mulai jenuh dalam berkerja, karyawan yang berkeinginan untuk melakukan pindah kerja, akan lebih malas berkerja karena orientasi karyawan ini adalah berkerja di tempat lainnya yang dipandang lebih mampu memenuhi semua keinginan karyawan bersangkutan.

3. Peningkatan pelanggaran tata tertib kerja, berbagai pelanggaran terhadap tata tertib dalam lingkungan pekerjaan sering dilakukan karyawan yang akan melakukan turnover intention.

4. Tingkat proter kepada atasan, karyawan yang berkenginan untuk melakukan pindah kerja, lebih sering melakukan proter terhadap kebijakan-kebijakan perusahaan kepada atasan.

5. Perilaku positif yang berbeda dari biasanya, biasanya hal ini berlaku untuk karyawan yang karakteristik positif.
Tingkat kepuasan kerja Aparatur Desa menjadi salah satu cara mengoptimalkan kinerja dari Aparatur Desa tersebut. Menurut Locke dalam Kaswan (2015) definisi komprehensif dari kepuasan kerja yang meliputi reaksi atau sifat kognitif, afektif, dan evaluatif dan menyatakan bahwa kepuasan kerja adalah keadaan emosi senang atau emosi positif yang berasal dari penilaian pekerjaan atau pegalaman kerja seseorang. Kepuasan kerja adalah hasil dari persepsi karyawan mengenai seberapa baik pekerjaan mereka memberikan hal yang dinilai penting.

Issa et. al, dalam Dwiningtyas, 2015, mengemukakan ada lima indikator kepuasan, yaitu :

1. Kepuasan terhadap pekerjaan itu sendiri, seberapa besar pekerjaan itu memberi seseorang tugas yang menarik, kesempatan untuk belajar dan kesempatan untuk menerima tanggung jawab.

2. Kepuasan terhadap gaji, berapa besar imbalan financial yang diterima dan seberapa besar hal itu dianggap pantas/adil dibandingkan dengan imbalan di organisasi lain.

3. Kepuasan terhadap promosi, memiliki kesempatan untuk melakukan promosi potensi diri, sehingga potensi diri itu sebagai acuan untuk promosi jabatan.

4. Kepuasan terhadap pengawasan (Supervisi), kemampuan memberi bantuan teknis dan dukungan perilaku terhadap tugas dan kewajiban individu.

5. Kepuasan terhadap rekan kerja, seberapa besar rekan kerja terampil secara teknis dan secara sosial memberi dukungan dan motivasi dalam menyelesaikan tugas dan kewajiban.

Keragaman sumberdaya manusia, keinginan untuk berpindah dan kepuasan kerja dapat memberikan pengaruh terhadap pengembangan potensi Aparatur Desa tersebut. Menurut Richardson (dalam Aziz, 2014), indikator pengembangan adalah:

1. Efektivitas Pengembangan profesional pada Kebutuhan (Effectiveness of Professional Development on Own 
Employment Needs) yakni program pengembangan memiliki dampak pada pemenuhan kebutuhan akan kemampuan teknis dan konseptual yang akan digunakan dalam bekerja.

2. Efektivitas Pengembangan pada Tujuan Personal (Effectiveness of Professional Development on Personal Goals): yakni program pengembangan memiliki pengaruh terhadap tujuan personal dalam bekerja seperti peluang promosi, kenaikan jabatan, kenaikan gaji dan peluang melanjutkan studi.

3. Efektivitas Pengembangan pada pada Aspirasi Karir (Effectiveness of Professional Development on Career Aspirations) yakni program pengembangan memiliki pengaruh terhadap peningkatan kualifikasi, kompetensi, dan kapasitas yang memadai dalam aspirasi karir guna meningkatkan karir pekerjaanya.

\section{Gambaran Objek Penelitian}

Berdasarkan Peraturan Pemerintah Nomor 38 Tahun 2004, Teluk Bintan menjadi Ibu kota Kabupaten Bintan. Desa di Kabupaten Bintan berjumlah 36 Desa. Desa di Kecamatan Teluk Bintan Kabupaten Bintan Provinsi Kepulauan Riau yang berjumlah 6 Desa yaitu Desa Tembeling, Desa Bintan Buyu, Desa Penaga, Desa Pengujan, Desa Pangkil dan Desa Tembeling Tanjung yang sekarang telah melakukan pemekaran Desa menjadi Kelurahan. Pada penelitian ini responden data penelitian adalah aparatur Desa yang berada di Kecamatan Teluk Bintan Kabupaten Bintan.

\section{Demografi Responden}

Berdasarkan jenis kelamin maka terdapat 54 jiwa berjenis kelamin laki-laki dan 19 jiwa berjenis kelamis perempuan sehingga menciptakan rasio perbandingan 3:1. Berdasarkan usia maka terdapat 32 jiwa berusia 17-27 tahun, 27 jiwa berusia 28-37 tahun dan 14 jiwa berusia 38-60 tahun,. Berdasarkan tingkat pendidikan maka terdapat 60 jiwa berpendidikan SMA dan 11 jiwa berpendidikan S1 serta masing-masing 1 jiwa berpendidikan SD dan
SMP. Berdasarkan status maka terdapat 37 jiwa berstatus lajang dan 36 jiwa berstatus sudah menikah. Berdasarkan lama berkerja maka terdapat 55 jiwa yang telah berkerja dalam kurun waktu 1-10 tahun dan 15 jiwa telah berkerja dalam kurun waktu 11-20 tahun serta 3 jiwa telah berkerja diatas 20 tahun.

\section{Hasil Penelitian}

Penelitian ini melakukan uji kualitas data, uji asumsi klasik dan menganalisis regresi linear berganda dengan 73 data responden.

\section{Uji Kualitas Data}

Untuk mendapatkan data yang sesuai dan konsisten untuk dijadikan pengukuran penelitian maka dilakukan uji validitas dan reliabiltas data.

\section{Uji Validitas}

Berdasarkan uji validitas maka didapati bahwa data telah sesuai untuk dijadikan pengukuran penelitian. Dalam penelitian ini memuat 17 pertanyaan,yaitu gabungan pertanyaan dari variabel Pengembangan Potensi SDM sebanyak 4 butir pertanyaan, variabel Diversity sebanyak 5 butir pertanyaan, variabel Turnover Intention sebanyak 3 butir pertanyaan dan variabel Kepuasan Kerja sebanyak 5 pertanyaan yang ditanggapi oleh 73 responden. Kriteria yang digunakan dalam penelitian ini adalah tingkat kepercayaan $=95 \%$, dengan taraf kesalahan $\alpha$ $=5 \%$, untuk $\mathrm{n}=73(\mathrm{df}=\mathrm{n}-2)$ adalah 71 , maka rtabel adalah 0.230. Ini berdasarkan tabel r, jika rhitung> $r$ tabel maka pengujian validitas tersebut valid, karena $r$ hitung lebih besar dari $r$ tabel dan butir instrumen valid akan digunakan dalam penelitian, jika butir pertanyaan itu tidak valid maka tidak digunakan dalam penelitian ini.

\section{Uji Reliabilitas}

Berdasarkan uji reliabilitas maka didapati bahwa data telah konsisten untuk dijadikan pengukuran penelitian. Pada penelitian ini bahwa pernyataan kuesioner reliabel pada seluruh variabelnya karena mempunyai nilai Cronbach's Alphalebih dari 0.60. Hal ini menunjukkan bahwa setiap item pernyataan yang digunakan akan mampu memperoleh data yang konsisten, yang berarti bila pernyataan itu diajukan kembali akan 
diperoleh jawaban yang relatif sama dengan jawaban sebelumnya.

\section{Asumsi Klasik}

Untuk mendapatkan data yang normal, bersifat heterogen dan menyebar secara merata maka dilakukan uji normaliitas, multikolinearitas dan heteroskedastisitas.

\section{Uji Normalitas}

Dengan melihat nilai Kolmogorov-Smirnov dan nilai Asymp. Sig. (2-tailed) adalah $>0.05$ yaitu nilai Kolmogorov-Smirnov sebesar $\mathbf{0 . 9 9}$ dan nilai Asymp. Sig. (2-tailed) sebesar 0.072. Hal ini berarti data residual terdistribusi normal.

\section{Uji Multikolinearitas}

Hasil perhitungan menunjukkan nilai tolerance variabel independen memiliki nilai tolerance > 0,10 dan hasil perhitungan nilai VIF juga menunjukkan variabel independen memiliki nilai VIF $<10$. Dengan demikian dapat disimpulkan bahwa pada penelitian ini tidak terjadi multikolinearitas antar variabel independen dalam model regresi.

\section{Uji Heteroskedastisitas}

Hasil perhitungan menunjukkan tidak ada satupun variable independen yang signifikan secara statistic mempengaruhi variable dependen ABS_RES. Hal ini terlihat dari probabilitas signifikansinya diatas tingkat kepercayaan 5\% maka dapat disimpulkan model regresi tidak mengadung adanya heteroskedastisitas, sehingga model regresi layak dipakai untuk memprediksi pengembangan potensi aparatur desa berdasarkan masukan variabel independen diversity, turnover intention dan kepuasan kerja.

\section{Analisis Regresi Linear Berganda}

Analisis regresi linear berganda digunakan untuk mengetahui pengaruh variabel independen terhadap variabel dependen. Analisis regresi linear berganda didapat dari analisa hasil Uji $\mathrm{t}$ dan Uji F serta determinasi R Square.

\section{Uji t}

Uji t digunakan untuk mengetahui ada atau tidaknya pengaruh masing-masing independen secara individual terhadap variabel dependen. Jika nilai probabilitas atau signifikansi $\alpha>0,05$ maka variabel bebas secara parsial tidak berpengaruh terhadap pengembangan potensi aparatur, jika $\alpha<0.05$ maka variabel bebas secara parsial berpengaruh terhadap pengembangan potensi aparatur. Sedangkan ttabel yang dicari pada alpha 0.05 (two tailed) adalah 1.994. Uji ini juga dilakukan dengan membandingkan $t$ hitung dengan $t$ tabel dengan ketentuan jika $t$ hitung $<\mathrm{t}$ tabel, atau $-\mathrm{t}$ hitung $>$ - $\mathrm{t}$ tabel, maka $\mathrm{H} 0$ diterima atau jika $\mathrm{t}$ hitung $>\mathrm{t}$ tabel, atau - $\mathrm{t}$ hitung < - $\mathrm{t}$ tabel, maka H1 diterima. Berdasarkan nilai signifikan sebagai dasar pengambilan keputusan adalah jika nilai Sig. $>\alpha$, untuk $\alpha=5 \%$, maka $\mathrm{H} 0$ diterima atau jika Sig. $<\alpha$, untuk $\alpha=5 \%$, maka H1 diterima.

Hasil analisis regresi linear berganda maka didapat bahwa secara parsial variable Diversity dan variable Kepuasan Kerja berpengaruh terhadap variable Pengembangan Potensi. Namun secara parsial variable Turnover Intention tidak berpengaruh terhadap variable Pengembangan Potensi.

\section{Uji F}

Uji $\mathrm{F}$ ini digunakan untuk mengetahui pengaruh semua variabel independen yang dimasukkan dalam model regresi secara bersama-sama terhadap variabel dependen yang diuji pada tingkat signifikan 0.05. Tingkat signifikan adalah sebesar $5 \%$ dengan degree of freedom (df) $=n-4-k=69$ Sehingga Ftabel $=2.74$. Uji ini dilakukan dengan membandingkan signifikan $\mathrm{F}$ hitung dengan $\mathrm{F}$ tabel dengan ketentuan jika $\mathrm{F}$ hitung < $\mathrm{F}$ tabel, maka $\mathrm{H} 0$ diterima atau jika $\mathrm{F}$ hitung > $\mathrm{F}$ tabel, maka $\mathrm{H} 1$ diterima. Berdasarkan nilai signifikan sebagai dasar pengambilan keputusan adalah jika nilai Sig $>\alpha$, untuk $\alpha=5 \%$, maka $\mathrm{H} 0$ diterima atau jika nilai $\mathrm{Sig}<\alpha$, untuk $\alpha=5 \%$, maka $\mathrm{H} 1$ diterima. Secara simultan ketiga variable independen tersebut berpengaruh terhadap variable Pengembangan Potensi.

\section{Determinasi R Square}

Analisis determinasi dalam regresi linear berganda digunakan untuk mengetahui persentase sumbangan pengaruh variabel independen secara serentak terhadap variabel 
dependen. Dari tabel diatas dapat dilihat bahwa angka $\mathrm{R}$ disebut koefisien korelasi antara variabel Diversity, Turnover Intention dan Kepuasan Kerja dengan Pengembangan Potensi SDM adalah 0.836. Ini artinya hubungan antara variabel Diversity, Turnover Intention dan Kepuasan Kerja dengan Pengembangan Potensi SDM adalah kuat (signifikan) sebesar 83.6\%. Adjusted R2 dalam penelitian ini adalah 0.686 hal ini menujukkan bahwa sebesar $68.6 \%$ Pengembangan Potensi SDM pada Kantor Desa Kecamatan Teluk Bintan dipengaruhi oleh Diversity, Turnover Intention dan Kepuasan Kerja. Sedangkan sisanya sebesar 31,4 \% dipengaruhi atau dijelaskan oleh faktor-faktor lain yang tidak dimasukkan dalam penelitian ini.

Tabel 1. Ringkasan Uji t, Uji F dan $\mathbf{R}^{2}$

\begin{tabular}{|c|c|c|c|c|c|}
\hline \multicolumn{3}{|c|}{ UJI T } & \multicolumn{2}{|c|}{ UJI F } & \multirow{2}{*}{$\begin{array}{l}\mathbf{R}^{2} \\
70 \\
\%\end{array}$} \\
\hline $\begin{array}{l}\text { Divers } \\
\text { ity }\end{array}$ & $\begin{array}{l}\text { Sig. } \\
0.0 \\
04\end{array}$ & $\begin{array}{l}\text { Berpeng } \\
\text { aruh }\end{array}$ & \multirow[t]{3}{*}{$\begin{array}{l}\text { Sig. } \\
535 \\
48\end{array}$} & \multirow[t]{3}{*}{$\begin{array}{l}\text { Berpeng } \\
\text { aruh }\end{array}$} & \\
\hline $\begin{array}{l}\text { Turno } \\
\text { ver } \\
\text { Intenti } \\
\text { on }\end{array}$ & $\begin{array}{l}\text { Sig. } \\
0.2 \\
09\end{array}$ & $\begin{array}{l}\text { Tidak } \\
\text { berpeng } \\
\text { aruh }\end{array}$ & & & \\
\hline $\begin{array}{l}\text { Kepua } \\
\text { san } \\
\text { Kerja }\end{array}$ & $\begin{array}{l}0.0 \\
38\end{array}$ & $\begin{array}{l}\text { Berpeng } \\
\text { aruh }\end{array}$ & & & \\
\hline
\end{tabular}

Sumber: Olahdata Penulis

\section{Kesimpulan}

Berdasarkan olahdata dapat disimpulkan bahwa jika diukur secara parsial maka diversity atau keragaman sumberdaya manusia dengan klasifikasi demografi jenis kelamin, usia, masa jabatan, status dan tingkat pendidikan berpengaruh terhadap pengembangan potensi aparatur desa. Tingkat kepuasan kerja pegawai juga berpengaruh terhadap pengembangan potensi secara parsial. Namun turnover intention atau keinginan berpindah kerja tidak berpengaruh terhadap pengembangan potensi. Jika diukur secara simultan ketiga variable tersebut dapat mempengaruhi pengembangan potensi dengan besaran pengaruh mencapai $70 \%$. Sehingga penulis menyimpulkan bahwa kebijakan yang tepat dalam mengelola keberagaman sumberdaya manusia dan terus menjaga tingkat kepuasan kerja maka pengembangan potensi dapat dilakukan secara optimal. Dengan berkembangnnya potensi aparatur desa secara optimal maka akan meningkatkan kontribusi terhadap perwujudan visi dan misi pemerintah.

\section{Ucapan Terimakasih}

Terimakasih kepada pihak terkait yang telah membantu penulis dalam menyelesaikan penelitian dengan judul Pengaruh Diversity, Turnover Intention dan Kepuasan Kerja Terhadap Pengembangan Potensi Aparatur Desa TEluk Bintan Kabupaten Bintan Provinsi Kepulauan Riau Tahun 2019.

\section{Daftar Pustaka}

Adi, Wijaya Rangga. (2014). Pengaruh Diversity Management Terhadap Turnover Intention Dengan Job Satisfaction Sebagai Variabel Intervening (Studi Pada Universitas Kristen Satya Wacana). Universitas Kristen Satya Wacana Salatiga

Akbar, Zahrifa, A. (2013). Pengaruh Kepuasan Kerja Terhadap Turnover Intention Tetap.

Depok : Universitas Indonesia.

Arikunto, S. (2013). Prosedur Penelitian : Suatu Pendekatan Praktik. Jakarta. Rineka Cipta. Bangun, Wilson. 2012. Manajemen Sumber Daya Manusia. Erlangga. Jakarta

Dwiningtyas. (2017). Pengaruh Kepuasan Kerja, Stres Kerja, Dan Lingkungan Kerja Terhadap Turnover Intention Pada Karyawan. Universitas Negeri Semarang. Semarang

Gaol, J. L. (2014). Human Capital MSDM. Jakarta: Gramedia. 
Jurnal Bahtera Inovasi Vol. 3 No. 2 Tahun 2020

@ Program Studi Manajemen

FE Universitas Maritim Raja Ali Haji

Robbin and Coulter (2012), Management, Upper

Saddle River, 11th Editions, New Jersey,Prentice Hall

Rusmayanti, Nanda Dwi. (2014). Pengaruh Kepuasan Kerja Terhadap Intensi Keluar Karyawan Tetap pada Head Office PT X Jakarta. Depok: Universitas Indonesia.

Santoso. J. (2014). Panduan Lengkap SPSS Versi 20. Edisi Revisi. Jakarta: Elex Media Computindo.

Setio, Yusup Budi dan Samuel PD Anantadjaya.(2014). Peran Personal Diversity, Kompetensi \& Kinerja Karyawan Di Beberapa Perusahaan Di Indonesia. ISSN 2338-8854 Insight EmergINg Markets: BuSIness and ManaGement STudies Journal.Vol. 2, No. 2, September 2014.

Wulandari, Valentina Ade Putri (2017). Pengaruh Kepuasan Kerja Karyawan Terhadap Turnover Intention. Universitas Sanata Dharma. Yogyakarta 